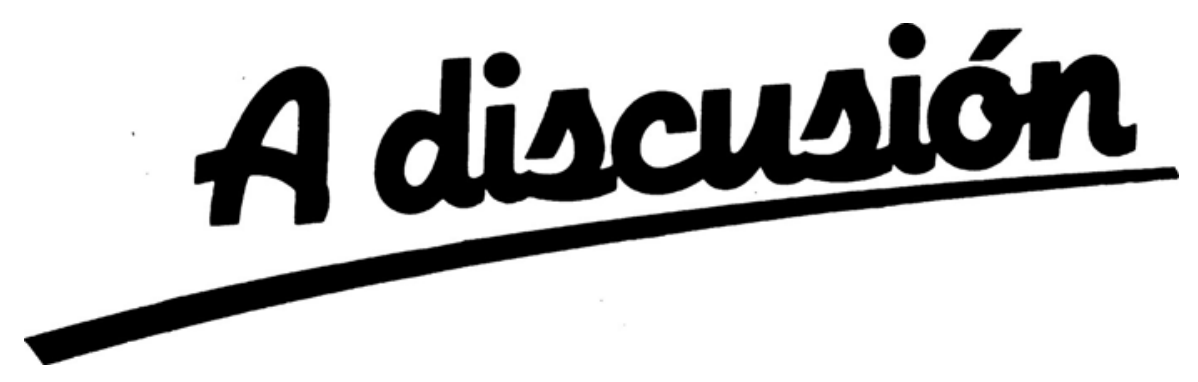

\title{
PURCHASING POWER PARITY IN CENTRAL AND EASTERN EUROPEAN COUNTRIES: AN ANALYSIS OF UNIT ROOTS AND NONLINEARITIES*
}

\author{
Juan Carlos Cuestas
}

WP-AD 2007-22

Correspondence: Nottingham Business School, Division of Economics, Nottingham Trent University, Burton Street, NG1 4BU, Nottingham, UK. e-mail:juan.cuestas@ntu.ac.uk.

Editor: Instituto Valenciano de Investigaciones Económicas, S.A.

Primera Edición Octubre 2007

Depósito Legal: V-4641-2007

Ivie working papers offer in advance the results of economic research under way in order to encourage a discussion process before sending them to scientific journals for their final publication.

* The author gratefully acknowledges the financial support from the CICYT and FEDER project SEJ2005-01163, the Bancaja project P1.1B2005-03 and the Generalitat Valenciana Complementary Action ACOMP07/102. The author is a member of the INTECO research group. The usual disclaimer applies. 


\title{
PURCHASING POWER PARITY IN CENTRAL AND EASTERN EUROPEAN COUNTRIES: AN ANALYSIS OF UNIT ROOTS AND NONLINEARITIES
}

\author{
Juan Carlos Cuestas
}

\begin{abstract}
The aim of this paper is to analyse the empirical fulfilment of PPP in a number of Central and Eastern European countries. For this purpose we apply two different unit root tests in order to control for two sources of nonlinearities, i.e. Bierens (1997) and Kapetanios, Shin and Snell (2003). We find that PPP holds in most of these countries once account has been taken of nonlinear deterministic trends and smooth transitions.
\end{abstract}

Keywords: PPP, Real Exchange Rate, Unit Roots, nonlinearities, Central and East Europe.

JEL codes: C32, F15. 


\section{Introduction}

The analysis of Purchasing Power Parity (PPP hereafter) has probably been one of the most controversial topics of the last decades within international economics. Its empirical validity has important implications, not only because it is the base line of a number of macroeconomic models, but also because it is commonly used as a benchmark to analyse the overvaluation or undervaluation of currencies and as a measure of economic integration among countries (see Wei and Parsley, 1995, among others).

In short, PPP implies that the Real Exchange Rate (RER hereafter) should be equal to 1 , that is

$$
q_{t}=\frac{s_{t} p_{t}}{p_{t}^{*}}=1
$$

where $q_{t}$ is the real exchange rate, $s_{t}$ is the nominal exchange rate ${ }^{1}$, and $p_{t}^{*}$ and $p_{t}$ are respectively the foreign and domestic price indices.

The empirical analysis of PPP has reached different stages depending on the evolution of the econometric techniques available. Early authors aimed to regress the nominal exchange rate on the price indices by simple OLS and Instrumental Variables methods (see Frenkel, 1978 and Krugman, 1978 for instance), while recent advances in econometrics have provided more accurate tools with which to analyse PPP fulfilment empirically, such as nonlinear techniques (Obstfeld and Taylor, 1997; Sarno, 2000; Camarero, Cuestas and Ordóñez, 2006a, 2006b, among others).

In practice, it is generally accepted that if PPP holds, it does so only in the long run and therefore, shocks affecting the RER have effects only on the dynamics of the variable. This stylised fact implies that the RER has to be stationary for PPP to be fulfilled empirically ${ }^{2}$.

As mentioned earlier, the more recent contributions to the analysis of PPP focus on the application of techniques that take into account the existence of nonlinearities. The use of these techniques is justified by at least three main reasons. The first one is related to the fact that the existence of trade barriers and, therefore, absence of arbitrage within a threshold of exchange rate values, yields to a nonlinear behaviour in the path of the variable (Dumas 1992; Taylor and Peel, 2000; Taylor, Peel and Sarno, 2001; and Kilian and Taylor, 2003). Additionally, Taylor (2004) claims that interventions

\footnotetext{
${ }^{1}$ Units of foreign currency for a unit of domestic currency.

${ }^{2}$ While the absence of stochastic trends is a necessary condition for PPP to hold, the existence of a time trend or broken time trend can be considered as a weak form of PPP or quasi-PPP (Hegwood and Papell, 1998).
} 
in the foreign currency markets might generate a nonlinear behaviour in the RER path, where the RER is a unit root process for central values within a threshold, but stationary when it is outside of the threshold. Finally, the existence of structural changes in the RER might imply broken deterministic time trends. If one generalises these broken time trends, the result is a nonlinear deterministic trend (Bierens, 1997).

The presence of these two types of nonlinearities has implications for the power of the technique applied to analyse the order of integration of the variables. In both cases traditional unit root tests suffer from important power distortions, i.e. tendency to accept a false unit root null hypothesis (Perron and Phillips, 1987; West, 1988; Bierens, 1997; and Kapetanios, Shin and Snell, 2003, among others).

In this paper we analyse whether PPP holds in several Central and Eastern European countries (CEECs hereafter): Bulgaria, Croatia, the Czech Republic, Hungary, Macedonia, Poland, Romania and the Slovak Republic; due to their increasing importance in view of joining the UEM or the EU (depending on the country). During recent years, a number of authors have tested for the empirical validity of PPP in CEECs. In Table 1, we report a brief summary of the main contributions to the empirical analysis of PPP in this group of countries. From this table, it is possible to highlight several common features. First, all of the contributions focus on the exchange rate against the US dollar or European currencies, mainly because of the importance of these two areas in the external trade of those countries; second, the results in favour of PPP are in general pretty weak; finally, in almost all of them ,the authors apply unit root tests and cointegration techniques without paying attention to the possibility of nonlinearities in the long run behaviour of the RER, which might bias the results towards the failure of PPP.

In order to test for PPP in the CEECs, in this study we apply two different unit root tests in order to take into account different possibilities regarding nonlinearities in the RER long run path, i.e. Bierens (1997) and Kapetanios, Shin and Snell (2003) unit root tests.

The remainder of this paper is organised as follows. In the next section we present a brief description of these two unit root tests. Section 3 analyses the results of applying these tests and, finally, the last section concludes with the main conclusions.

\section{Econometric Methodology}

In this paper we control for two sources of nonlinearities in the Real Exchange Rates when applying unit root tests. First, nonlinearities can be present in 
Table 1: Brief literature review on the PPP analysis in CEEC's

\begin{tabular}{|c|c|c|c|c|c|}
\hline Reference & CEEC & $\begin{array}{l}\text { Numeraire } \\
\text { currency }\end{array}$ & Period & Approach & Results \\
\hline Thacker (1995) & $\begin{array}{l}\text { Poland \& Hun- } \\
\text { gary }\end{array}$ & $\begin{array}{l}\text { GB pound, } \\
\text { U.S. \$ \& } \\
\text { Deutsche } \\
\text { Mark }\end{array}$ & $\begin{array}{l}\text { 1981:1-1993:2 } \\
\text { (Hungary) } \\
\text { 1982:1-1993:2 } \\
\text { (Poland) } \\
\text { (Monthly data) }\end{array}$ & $\begin{array}{l}\text { Phillips-Perron } \\
\text { cointegration } \\
\text { and unit root } \\
\text { test }\end{array}$ & Rejection \\
\hline $\begin{array}{l}\text { Choudhry } \\
\text { (1999) }\end{array}$ & $\begin{array}{l}\text { Poland, Roma- } \\
\text { nia \& Slovenia }\end{array}$ & U.S. \$ & $\begin{array}{l}\text { 1991:1-1996:9 } \\
\text { (Poland); } \\
\text { 1991:12-1997:5 } \\
\text { (Romania); } \\
\text { 1991:10-1997:5 } \\
\text { (Slovenia) } \\
\text { (Monthly data) }\end{array}$ & $\begin{array}{l}\text { Harris-Inder test } \\
\text { for cointegration } \\
\& \quad \text { Fractional } \\
\text { cointegration }\end{array}$ & $\begin{array}{l}\text { Slovenia: frac- } \\
\text { tional cointe- } \\
\text { gration; Poland, } \\
\text { Romania \& } \\
\text { Slovenia: } \\
\text { Harris-Inder } \\
\text { cointegration }\end{array}$ \\
\hline $\begin{array}{ll}\text { Christev } & \& \\
\text { Noorbakhsh } & \\
(2000) & \end{array}$ & $\begin{array}{l}\text { Bulgaria, Czech } \\
\text { Republic, Hun- } \\
\text { gary, Poland, } \\
\text { Romania \& } \\
\text { Slovak Republic }\end{array}$ & $\begin{array}{l}\text { U.S. \$, } \\
\text { Deutsche } \\
\text { Mark \& } \\
\text { ECU }\end{array}$ & $\begin{array}{l}\text { 1990:1-1998:11 } \\
\text { (Monthly data) }\end{array}$ & $\begin{array}{l}\text { Stock-Watson } \\
\text { Dynamic OLS \& } \\
\text { Johansen }\end{array}$ & $\begin{array}{l}\text { Weak support to } \\
\text { PPP }\end{array}$ \\
\hline Barlow (2003) & $\begin{array}{l}\text { Czech Republic, } \\
\text { Poland \& Roma- } \\
\text { nia }\end{array}$ & $\begin{array}{l}\text { Geometric } \\
\text { average } \\
\text { between } \\
\text { U.S. \& \& } \\
\text { Deutsche } \\
\text { Mark }\end{array}$ & $\begin{array}{l}\text { 1994:4-2000:12 } \\
\text { (Monthly data) }\end{array}$ & $\begin{array}{l}\text { ADF unit root } \\
\text { test \& Johansen }\end{array}$ & Rejection \\
\hline Sideris (2006) & $\begin{array}{l}\text { Bulgaria, Croa- } \\
\text { tia, Czech Rep., } \\
\text { Hungary, Mace- } \\
\text { donia, Poland, } \\
\text { Romania, Slovak } \\
\text { Rep. \& Slovenia }\end{array}$ & U.S. $\$$ & $\begin{array}{l}\text { 1990:1-2004:1 } \\
\text { (Quarterly data) }\end{array}$ & $\begin{array}{l}\text { Johansen } \& \\
\text { Larsson et al. } \\
(2001) \text { panel } \\
\text { cointegration }\end{array}$ & $\begin{array}{l}\text { Weak support to } \\
\text { PPP }\end{array}$ \\
\hline $\begin{array}{l}\text { Giannellis \& } \\
\text { Papadopoulos } \\
(2006)\end{array}$ & $\begin{array}{l}\text { Czech Rep., } \\
\text { Hungary, Poland } \\
\text { \& Slovak Rep. }\end{array}$ & $\begin{array}{l}\text { EURO, } \\
\text { U.S. \$ \& } \\
\text { Effective } \\
\text { exchange } \\
\text { rate }\end{array}$ & $\begin{array}{l}\text { 1991:1-2003:8 } \\
\text { (Czech Rep.) } \\
\text { 1995:1-2003:8 } \\
\text { (Poland) 1993:1- } \\
\text { 2003:8 (Slovak } \\
\begin{array}{l}\text { Rep.) (Monthly } \\
\text { data) }\end{array}\end{array}$ & $\begin{array}{lr}\text { Unit } & \text { roots } \\
\text { with } & \text { struc- } \\
\text { tural changes \& } \\
\text { Johansen }\end{array}$ & $\begin{array}{l}\text { Weak evidence } \\
\text { applying unit } \\
\text { root tests, PPP } \\
\text { holds in } 6 \text { up to } \\
8 \text { cases applying } \\
\text { cointegration }\end{array}$ \\
\hline Masters (2006) & $\begin{array}{lr}\text { Czech } & \text { Rep., } \\
\text { Hungary, } & \\
\text { Poland, } & \text { Slo- } \\
\text { vak Rep. } & \& \\
\text { Slovenia } & \end{array}$ & EURO & $\begin{array}{l}\text { 1993:1-2003:10 } \\
\text { (Monthly data) }\end{array}$ & $\begin{array}{l}\text { Unit root tests, } \\
\text { Cointegration } \\
\text { (Engle-Graner } \\
\text { \& Johansen) \& } \\
\text { TAR \& TAR-M } \\
\text { cointegration \& } \\
\text { (Enders \& } \\
\text { Granger, 1998) }\end{array}$ & $\begin{array}{l}\text { Favorable to } \\
\text { PPP in Czech } \\
\text { Rep. Hungary } \\
\text { \& Slovak Rep. }\end{array}$ \\
\hline Beirne (2007) & $\begin{array}{l}\text { Bulgaria, Czech } \\
\text { Rep., Hungary, } \\
\text { Poland, Roma- } \\
\text { nia, Slovak Rep. } \\
\text { \& Slovenia }\end{array}$ & $\begin{array}{l}\text { U.S. \$ \& } \\
\text { EURO }\end{array}$ & $\begin{array}{l}\text { 1999:1-2006:9 } \\
\text { (Monthly data) }\end{array}$ & $\begin{array}{l}\text { Johansen } \& \\
\text { Larsson et al. } \\
(2001) \text { panel } \\
\text { cointegration }\end{array}$ & $\begin{array}{l}\text { Weak evidence } \\
\text { in favour of PPP }\end{array}$ \\
\hline
\end{tabular}


variables in the form of different behaviour of the variable depending on its values, i.e. the variable behaves as a nonstationary process when it is within a band, but behaves as a stationary variable when it is outside of the threshold. As stated by Dumas (1994) and Michael, Nobay and Peel 1997, among others, it is sensible to assume that the shift between regimes is smooth rather than sudden, due to time aggregation and individuals behaviour. Additionally, it is very likely that the series of the RER of these countries has suffered from structural changes during the transition period. One way to take these changes into account, suggested by Bierens (1997) among others, is approximating the broken time trends by nonlinear trends.

Thus, we have applied two groups of unit root tests. Firstly, we apply the Kapetanios, Shin and Snell (2003) (KSS hereafter) unit root test. These authors propose a unit root test that takes into account the possibility of smooth transitions between regimes. Thus, the null hypothesis of unit root is tested against the alternative of globally stationary exponential smooth transition autoregressive (ESTAR hereafter) process, i.e.

$$
x_{t}=\beta x_{t-1}+\phi x_{t-1}\left(1-e^{-\theta x_{t-1}^{2}}\right)+\epsilon_{t}
$$

where $\epsilon_{t} \sim i i d\left(0, \sigma^{2}\right)$. Equation (2.1) can be reparameterised as

$$
\Delta x_{t}=\alpha x_{t-1}+\gamma x_{t-1}\left(1-e^{-\theta x_{t-1}^{2}}\right)+\epsilon_{t} .
$$

KSS impose $\alpha=0$, implying that the variable is a nonstationary process in the central regime. In order to test the null hypothesis of unit root $H_{0}: \theta=0$ against $H_{1}: \theta>0$ outside of the threshold ${ }^{3}$, Kapetanios et al. (2003) propose a Taylor approximation of the ESTAR model since, in practice, the coefficient $\gamma$ cannot be identified under $H_{0}$. Thus, under the null, the model becomes

$$
\Delta x_{t}=\delta x_{t-1}^{3}+\eta_{t}
$$

where $\eta_{t}$ is an error term. Now, it is possible to apply a $t$-test to analyse whether $x_{t}$ is a nonstationary process, $H_{0}: \delta=0$, or is a nonlinear stationary process, $H_{1}: \delta<0$.

The second tests are Bierens' (1997) unit root tests. With this approach we take into account the second source of nonlinearities discussed earlier. Bierens (1997) generalises the ADF auxiliary regression to incorporate Chebishev polynomials in order to approximate a nonlinear deterministic time trend $^{4}$, i.e.

\footnotetext{
${ }^{3}$ The process is globally stationary provided that $-2<\phi<0$.

${ }^{4}$ Following Bierens (1997) the use of Chebishev polynomials instead of regular time polynomials (Ouliaris, Park and Phillips, 1989) to approximate the nonlinear deterministic
} 


$$
\Delta x_{t}=\alpha x_{t-1}+\sum_{j=1}^{p} \phi_{j} \Delta x_{t-j}+\theta^{T} P_{t, n}^{(m)}+\varepsilon_{t}
$$

where $P_{t, n}^{(m)}$ are the Chebishev polynomials and $m$ is the order of the polynomials. The null hypothesis is formulated such as $\alpha$ and the last $m$ components of $\theta$ are equal to zero. In order to test for this hypothesis Bierens (1997) proposes several tests. The first is a $t$-test over the coefficient $\alpha, \hat{t}(m)$; likewise, this hypothesis can be tested applying the $\hat{A}(m)=\frac{n \hat{\alpha}}{\left|1-\sum_{i=1}^{p} \hat{\phi}_{i}\right|}$ test; the third one is an $F$-test for the joint hypothesis that $\hat{\alpha}$ and the last $m$ components of the parameter vector $\theta$ in model (2.4) are zero under the null, $\hat{F}(m)$. Note that the implications over the alternative hypothesis depend upon the side of the rejection. For the $\hat{t}(m)$ and $\hat{A}(m)$ test, left side rejection implies mean stationarity, linear trend stationarity or nonlinear trend stationarity without being able to distinguish which one of these possibilities; right side rejection implies nonlinear trend stationarity. With the $\hat{F}(m)$, which is a one-sided test, we reject the null hypothesis only when right side rejection is obtained, not being able to distinguish between the three possibilities (see Table 2).

Table 2: Alternative hypotheses

\begin{tabular}{ccc}
\hline \hline Test & Left-side rejection & Right-side rejection \\
\hline$\hat{t}(m)$ & MS, LTS or NLTS & NLTS \\
$\hat{A}(m)$ & MS, LTS or NLTS & NLTS \\
$\hat{F}(m)$ & - & MS, LTS or NLTS \\
\hline \hline
\end{tabular}

Note: $\mathrm{MS}=$ mean stationarity, LTS $=$ linear trend stationarity, NLTS $=$ nonlinear trend stationarity.

\section{$3 \quad$ Empirical Results}

The data used for this empirical analysis come from the International Financial Statistics CD-Rom database from the IMF. We have used three different RER. Firstly, the Real Effective Exchange Rate (REER hereafter), $q_{t}^{F}$, computed by the IMF as the rate of exchange against a basket of currencies of the main trade partners. This data spans from January, 1992 to February, 2007. Additionally we have computed a CPI-based RER against the US

trend creates less power distortions. 
dollar, $q_{t}^{U S}$, and the Euro/ECU ${ }^{5}, q_{t}^{E U}$, using for the latter the Harmonised Consumer Price Index. Data for these two bilateral RER span December, 1993 to October, 2006. The frequency of data is monthly.

As a preliminary analysis, we display in Table 3 the results of the $\mathrm{Ng}$ and Perron (2001) unit root tests. These are modified versions of existing (linear) unit root tests with better performance in terms of power and size distortions $^{6}$. It is possible to establish from Table 3 that, in almost all the cases, it is not possible to reject the unit root null hypothesis.

Nevertheless, the picture is somehow different after applying the differing unit root tests Kapetanios et al. (2003) and Bierens (1997). In Table 4, we report the results of applying the former test. These authors provide the critical values for different sample sizes. However, in order to obtain more accurate critical values for our sample size, we have computed them by Monte Carlo simulation based on 50,000 replications. Thus, in Croatia, it is possible to reject the null hypothesis when using the REER as well as for the RER vs. the Euro/ECU. In the case of Bulgaria, the RER appears to be stationary when computed against the US dollar and the Euro/ECU. Finally, we cannot reject the null hypothesis in Macedonia for the REER and Romania for the RER vs. the US dollar and vs. the Euro/ECU.

The existence of mean reversion in these cases implies that whereas the RER is not stationary within a certain threshold of values, it is stationary and tends to revert to the fundamentals when it is outside the threshold. In other words, the more deviated the RER is from its equilibrium value, the faster the reversion will be to the equilibrium given by the fundamentals (Taylor and Peel, 2000; and Kilian and Taylor, 2003). As mentioned earlier, trade barriers, as well as interventions in the exchange markets, could be behind this nonlinear behaviour.

As discussed before, we have also performed Bierens' (1997) unit root tests. These results are reported in Table 5. Note that, since these tests suffer from important size distortions (Bierens, 1997), the critical values have been obtained by Monte Carlo experiment based on 5,000 replications of a Gaussian $A R(m)$ process for $\Delta x_{t}$. The parameters and error variances are equal to the estimated $A R(m)$ null model, where the order $p$ of the ADF auxiliary regression has been obtained by the AIC and the initial values have been taken from the actual series. Firstly, the results from Table 5 indicate stronger evidence in favour of the PPP hypothesis. For instance, in the case of Bulgaria and Hungary it is possible to reject the null hypothesis of

\footnotetext{
${ }^{5}$ From the beginning of the sample to December, 1999 we have used the ECU exchange rates. After this date, the Euro exchange rate is used.

${ }^{6}$ See Ng and Perron (2001) for further details.
} 
Table 3: Ng and Perron (2001) unit root tests results

\begin{tabular}{l|c|cccc}
\hline \hline Country & Variable & $M Z_{\alpha}^{G L S}$ & $M Z_{t}^{G L S}$ & $M S B^{G L S}$ & $M P_{T}^{G L S}$ \\
\hline Bulgaria & $q_{t}^{F}$ & -6.07 & -1.71 & 0.28 & 14.98 \\
& $q_{t}^{U S}$ & -10.33 & -2.27 & 0.21 & 8.83 \\
& $q_{t}^{E U}$ & -9.18 & -2.12 & 0.23 & 9.97 \\
\hline Croatia & $q_{t}^{F}$ & -5.76 & -1.65 & 0.28 & 15.72 \\
& $q_{t}^{U S}$ & -3.05 & -1.19 & 0.39 & 28.84 \\
& $q_{t}^{E U}$ & -13.28 & -2.53 & 0.19 & 7.11 \\
\hline Czech Republic & $q_{t}^{F}$ & -9.96 & -2.22 & 0.22 & 9.19 \\
& $q_{t}^{U S}$ & -6.35 & -1.76 & 0.27 & 14.34 \\
& $q_{t}^{E U}$ & -6.27 & -1.69 & 0.26 & 14.52 \\
\hline Hungary & $q_{t}^{F}$ & -8.15 & -1.95 & 0.23 & 11.36 \\
& $q_{t}^{U S}$ & -2.14 & -0.98 & 0.45 & 39.70 \\
& $q_{t}^{E U}$ & -9.02 & -2.11 & 0.23 & 10.11 \\
\hline Macedonia & $q_{t}^{F}$ & -0.04 & -0.04 & 1.02 & 203.07 \\
& $q_{t}^{U S}$ & -2.87 & -1.19 & 0.41 & 31.62 \\
& $q_{t}^{E U}$ & -1.58 & -0.84 & 0.53 & 53.51 \\
\hline Poland & $q_{t}^{F}$ & -10.94 & -2.32 & 0.21 & 8.38 \\
& $q_{t}^{U S}$ & -6.24 & -1.75 & 0.28 & 14.59 \\
& $q_{t}^{E U}$ & -4.78 & -1.50 & 0.31 & 18.82 \\
\hline Romania & $q_{t}^{F}$ & $-14.60^{*}$ & $-2.68^{*}$ & $0.18^{*}$ & $6.36^{*}$ \\
& $q_{t}^{U S}$ & -6.55 & -1.72 & 0.26 & 13.95 \\
& $q_{t}^{E U}$ & -6.00 & -1.72 & 0.28 & 15.17 \\
\hline Slovak Republic & $q_{t}^{F}$ & -1.05 & -0.40 & 0.38 & 37.01 \\
& $q_{t}^{U S}$ & -3.39 & -1.25 & 0.36 & 25.94 \\
& $q_{t}^{E U}$ & $-14.83^{*}$ & $-2.72^{*}$ & $0.18^{*}$ & $6.14^{*}$ \\
\hline \hline
\end{tabular}

Note: The order of lag to compute the test has been chosen using the modified AIC (MAIC) suggested by Ng and Perron (2001). Rejection of the null hypothesis at the $10 \%$ significance level is given by ${ }^{*}$. The critical values for the above tests have been taken from Ng and Perron (2001):

\begin{tabular}{|c|c|c|c|c|}
\hline & $M Z_{\alpha}^{G L S}$ & $M Z_{t}^{G L S}$ & $M S B^{G L S}$ & $M P_{T}^{G L S}$ \\
\hline $1 \%$ & -23.80 & -3.42 & 0.14 & 4.03 \\
\hline $5 \%$ & -17.30 & -2.91 & 0.16 & 5.48 \\
\hline $10 \%$ & -14.20 & -2.62 & 0.18 & 6.67 \\
\hline
\end{tabular}


Table 4: KSS nonlinear unit root test results

\begin{tabular}{l|c|cc}
\hline \hline Country & Variable & lags & KSS statistic \\
\hline Bulgaria & $q_{t}^{F}$ & 6 & -2.92 \\
& $q_{t}^{U S}$ & 11 & $-5.36^{* * *}$ \\
& $q_{t}^{E U}$ & 7 & $-3.78^{* *}$ \\
\hline Croatia & $q_{t}^{F}$ & 14 & $-5.49^{* * *}$ \\
& $q_{t}^{U S}$ & 2 & -1.22 \\
& $q_{t}^{E U}$ & 1 & $-3.71^{* *}$ \\
\hline Czech Republic & $q_{t}^{F}$ & 2 & -2.58 \\
& $q_{t}^{U S}$ & 1 & -1.73 \\
& $q_{t}^{E U}$ & 10 & -1.90 \\
\hline Hungary & $q_{t}^{F}$ & 2 & -2.18 \\
& $q_{t}^{U S}$ & 2 & -1.30 \\
& $q_{t}^{E U}$ & 1 & -2.45 \\
\hline Macedonia & $q_{t}^{F}$ & 15 & $-3.49^{* *}$ \\
& $q_{t}^{U S}$ & 1 & -1.65 \\
& $q_{t}^{E U}$ & 0 & -2.22 \\
\hline Poland & $q_{t}^{F}$ & 1 & -2.81 \\
& $q_{t}^{U S}$ & 2 & -1.90 \\
& $q_{t}^{E U}$ & 1 & -2.48 \\
\hline Romania & $q_{t}^{F}$ & 3 & -0.58 \\
& $q_{t}^{U S}$ & 3 & $-4.09^{* * *}$ \\
& $q_{t}^{E U}$ & 3 & $-3.03^{*}$ \\
\hline Slovak Republic & $q_{t}^{F}$ & 0 & 1.82 \\
& $q_{t}^{U S}$ & 1 & -1.52 \\
& $q_{t}^{E U}$ & 1 & $-2.98^{\dagger}$ \\
\hline \hline
\end{tabular}

Note: The test has been computed including a constant and a linear time trend as deterministic component. The order of lag for the auxiliary regression has been selected by the AIC. Critical values at the $10 \%, 5 \%$ and $1 \%$ are $-3.00,-3.29$ and -3.87 , respectively and have been computed by Monte Carlo simulation with 50,000 replications. Rejection of the null hypothesis at the $10 \%, 5 \%$ and $1 \%$ significance level are given by the symbols ${ }^{*},{ }^{* *}$ and ${ }^{* * *}$, respectively. The symbol ${ }^{\dagger}$ implies quasi-rejection of the null. 
Table 5: Bierens (1997) nonlinear unit root test results

\begin{tabular}{l|c|ccc}
\hline \hline Country & Variable & $\hat{t}(m)$ & $\hat{A}(m)$ & $\hat{F}(m)$ \\
\hline Bulgaria & $q_{t}^{F}$ & $\mathbf{- 8 . 2 8}[\mathbf{0 . 0 4}]$ & $\mathbf{- 1 4 4 . 5 1}[\mathbf{0 . 0 5}]$ & $5.22[0.87]$ \\
& $q_{t}^{U S}$ & $\mathbf{- 8 . 8 2}[\mathbf{0 . 0 3}]$ & $\mathbf{- 1 7 3 . 8 0}[\mathbf{0 . 0 2}]$ & $5.48[0.80]$ \\
& $q_{t}^{E U}$ & $\mathbf{- 9 . 7 8}[\mathbf{0 . 0 6}]$ & $\mathbf{- 2 1 8 . 9 2}[\mathbf{0 . 0 6}]$ & $\mathbf{5 . 1 7}[\mathbf{0 . 6 7}]$ \\
\hline Croatia & $q_{t}^{F}$ & $\mathbf{- 8 . 0 4}[\mathbf{0 . 0 4}]$ & $\mathbf{- 3 0 7 . 9 6 [ 0 . 7 4 ]}$ & $\mathbf{7 . 1 0}[\mathbf{0 . 9 8}]$ \\
& $q_{t}^{U S}$ & $\mathbf{- 6 . 7 7}[\mathbf{0 . 0 3}]$ & $\mathbf{- 1 0 1 . 8 5}[\mathbf{0 . 0 2}]$ & $\mathbf{5 . 9 0}[\mathbf{0 . 9 7}]$ \\
& $q_{t}^{E U}$ & $\mathbf{- 6 . 0 5}[0.20]$ & $\mathbf{- 8 6 . 0 8}[\mathbf{0 . 0 9}]$ & $4.03[0.55]$ \\
\hline Czech Republic & $q_{t}^{F}$ & $\mathbf{- 4 . 9 3}[\mathbf{0 . 9 5}]$ & $\mathbf{- 4 7 . 0 0}[\mathbf{0 . 9 6}]$ & $2.49[0.05]$ \\
& $q_{t}^{U S}$ & $\mathbf{- 6 . 8 2}[0.32]$ & $\mathbf{- 1 0 6 . 4 3 [ 0 . 3 0 ]}$ & $3.95[0.48]$ \\
& $q_{t}^{E U}$ & $\mathbf{- 7 . 0 5}[0.26]$ & $\mathbf{- 1 0 9 . 0 1 [ 0 . 2 9 ]}$ & $4.17[0.57]$ \\
\hline Hungary & $q_{t}^{F}$ & $\mathbf{- 7 . 5 3}[\mathbf{0 . 0 8}]$ & $\mathbf{- 1 3 0 . 5 1}[\mathbf{0 . 0 6}]$ & $\mathbf{- 5 . 2 0}[\mathbf{0 . 9 0}]$ \\
& $q_{t}^{U S}$ & $\mathbf{- 7 . 1 8}[\mathbf{0 . 0 1}]$ & $\mathbf{- 1 6 7 . 3 6}[\mathbf{0 . 0 1}]$ & $\mathbf{7 . 3 3}[\mathbf{0 . 9 9}]$ \\
& $q_{t}^{E U}$ & $\mathbf{- 6 . 7 6}[\mathbf{0 . 0 3}]$ & $\mathbf{- 9 1 . 8 2}[\mathbf{0 . 0 4}]$ & $\mathbf{5 . 1 3}[\mathbf{0 . 9 1}]$ \\
\hline Macedonia & $q_{t}^{F}$ & $\mathbf{- 5 . 4 0}[0.87]$ & $\mathbf{- 8 3 . 4 6}[\mathbf{0 . 9 3}]$ & $3.52[0.22]$ \\
& $q_{t}^{U S}$ & $\mathbf{- 6 . 1 2}[0.11]$ & $\mathbf{- 8 1 . 5 4}[\mathbf{0 . 0 8}]$ & $\mathbf{5 . 5 4}[\mathbf{0 . 9 7}]$ \\
& $q_{t}^{E U}$ & $\mathbf{- 4 . 1 1}[0.35]$ & $\mathbf{- 2 7 . 8 6 [ 0 . 6 1 ]}$ & $\mathbf{6 . 0 8}[\mathbf{0 . 9 6}]$ \\
\hline Poland & $q_{t}^{F}$ & $\mathbf{- 3 . 9 6}[0.89]$ & $\mathbf{- 5 0 . 5 2 [ 0 . 8 4 ]}$ & $2.22[0.01]$ \\
& $q_{t}^{U S}$ & $-6.39[0.50]$ & $-134.03[0.53]$ & $3.61[0.30]$ \\
& $q_{t}^{E U}$ & $\mathbf{- 6 . 0 8}[\mathbf{0 . 9 0}]$ & $\mathbf{- 6 7 . 8 0}[\mathbf{0 . 9 1}]$ & $2.78[0.06]$ \\
\hline Romania & $q_{t}^{F}$ & $\mathbf{- 7 . 1 6}[0.23]$ & $\mathbf{- 1 0 7 . 1 6 [ 0 . 2 7 ]}$ & $4.54[0.69]$ \\
& $q_{t}^{U S}$ & $\mathbf{- 6 . 2 0}[0.57]$ & $\mathbf{- 1 2 7 . 1 2 [ 0 . 5 0 ]}$ & $3.83[0.51]$ \\
& $q_{t}^{E U}$ & $\mathbf{- 3 . 1 6}[\mathbf{0 . 9 2}]$ & $\mathbf{- 2 3 . 3 2}[\mathbf{0 . 9 2}]$ & $2.23[0.05]$ \\
\hline Slovak Republic & $q_{t}^{F}$ & $\mathbf{- 5 . 3 5}[0.87]$ & $\mathbf{- 5 2 . 0 2}[\mathbf{0 . 9 2}]$ & $3.17[0.26]$ \\
& $q_{t}^{U S}$ & $\mathbf{- 6 . 2 8}[0.11]$ & $\mathbf{- 8 8 . 4 9}[0.08]$ & $4.89[0.88]$ \\
& $q_{t}^{E U}$ & $\mathbf{- 4 . 4 4}[0.83]$ & $\mathbf{- 4 8 . 0 8 [ 0 . 7 5 ]}$ & $2.48[0.08]$ \\
\hline \hline
\end{tabular}

Note: P-values are reported in brackets. Rejections of the null hypothesis are reported in bold. Since the ADF test suffer from power problems when the deterministic trend is not properly specified (see Perron and Phillips, 1987, and West, 1988, among others), we have selected the order of $m$ that yields more evidence against the null hypothesis. 
unit root for the three different definitions of RER. Nevertheless, since we obtain left side rejection it is not possible to distinguish between mean stationarity, linear trend stationarity or stationarity around a nonlinear trend. Similar results are obtained in Croatia for the REER and the RER vs. the US dollar. Note that, for this country, the evidence in favour of the PPP hypothesis when using the RER vs. the Euro/ECU is very weak. Finally, in the Czech Republic (for the REER), Poland and Romania (for the RER vs. the Euro/ECU), the results point to stationarity around a nonlinear deterministic trend.

Overall, it is possible to summarise (see Table 6) that the evidence in favour of PPP is stronger after accounting for nonlinear deterministic trends. These nonlinear trends are meant to capture structural changes (Bierens, 1997 and 2000) during the transition period that have affected the RER long run path of these countries.

In contrast to the previous literature on PPP in these countries, we provide evidence that PPP holds in most of the CEECs once nonlinearities in the RER are taken into account.

\section{Conclusions}

In this paper, we have analysed the empirical fulfilment of the PPP theory in so-called Central and Eastern European Countries. The previous literature on this topic has mainly focused on the use of linear time series econometric techniques that, although appropriate to other more integrated areas and with further degree of development, have not accounted for the possibility of nonlinearities in the RER in this group of countries. Thus, the results obtained so far indicate poor evidence about the PPP hypothesis.

Contrary to the previous literature, we have applied two groups of unit root tests in order to control for different kinds of nonlinearities in the RER behaviour, that is, ESTAR models and nonlinear deterministic trends. Our results point to stronger evidence on the empirical fulfilment of PPP in these countries, once account has been taken of these sources of nonlinearities. 
Table 6: Summary of the results

\begin{tabular}{l|c|cc}
\hline \hline Country & Variable & KSS & Bierens (1997) \\
\hline Bulgaria & $q_{t}^{F}$ & no-PPP & PPP \\
& $q_{t}^{U S}$ & PPP & PPP \\
& $q_{t}^{E U}$ & PPP & PPP \\
\hline Croatia & $q_{t}^{F}$ & PPP & PPP \\
& $q_{t}^{U S}$ & no-PPP & PPP \\
& $q_{t}^{E U}$ & PPP & no-PPP \\
\hline Czech Republic & $q_{t}^{F}$ & no-PPP & PPP \\
& $q_{t}^{U S}$ & no-PPP & no-PPP \\
& $q_{t}^{E U}$ & no-PPP & no-PPP \\
\hline Hungary & $q_{t}^{F}$ & no-PPP & PPP \\
& $q_{t}^{U S}$ & no-PPP & PPP \\
& $q_{t}^{E U}$ & no-PPP & PPP \\
\hline Macedonia & $q_{t}^{F}$ & PPP & no-PPP \\
& $q_{t}^{U S}$ & no-PPP & PPP \\
& $q_{t}^{E U}$ & no-PPP & no-PPP \\
\hline Poland & $q_{t}^{F}$ & no-PPP & no-PPP \\
& $q_{t}^{U S}$ & no-PPP & no-PPP \\
& $q_{t}^{E U}$ & no-PPP & PPP \\
\hline Romania & $q_{t}^{F}$ & no-PPP & no-PPP \\
& $q_{t}^{U S}$ & PPP & no-PPP \\
& $q_{t}^{E U}$ & PPP & PPP \\
\hline Slovak Republic & $q_{t}^{F}$ & no-PPP & no-PPP \\
& $q_{t}^{U S}$ & no-PPP & no-PPP \\
& $q_{t}^{E U}$ & no-PPP & no-PPP \\
\hline \hline
\end{tabular}




\section{References}

Barlow, D. (2003): "Purchasing power parity in three transition economies", Economics of Planning, vol. 36, pp. 201-221.

Beirne, J. (2007): "Purchasing power parity in the European Union: A cointegrated approach and transition economies", Paper presented at the EEFS 2007 conference.

Bierens, H. J. (1997): "Testing the unit root with drift hypothesis against nonlinear trend stationarity, with an application to the U.S. price level and interest rate", Journal of Econometrics, vol. 81, pp. 29-64.

Bierens, H. J. (2000): "Nonparametric nonlinear co-trending analysis, with an application to inflation and interest in the U.S.", Journal of Business and Economic Statistics, vol. 18, pp. 323-337.

Camarero, M., J. C. Cuestas and J. Ordóñez (2006a): "Nonlinear trend stationarity of real exchange rates: The case of the Mediterranean countries", Working Papers. Serie AD 2006-27, Instituto Valenciano de Investigaciones Económicas, S.A. (Ivie).

Camarero, M., J. C. Cuestas and J. Ordóñez (2006b): "PPP versus the EU in the Mediterranean countries", Applied Financial Economics, vol. 16, pp. $157-167$.

Choudhry, T. (1999): "Purchasing power parity in high inflation Eastern European countries: Evidence from fractional cointegration and HarrisInder cointegration test", Journal of Macroeconomics, vol. 21, pp. 293308.

Christev, A. and A. Noorbakhsh (2000): "Long-run purchasing power parity, prices and exchange rates in transition: The case of six Central and East European countries", Global Finance Journal, vol. 11, pp. 87-108.

Dumas, B. (1992): "Dynamic equilibrium and the real exchange rate in a spatially separated world", Review of Financial Studies, vol. 5, pp. 153180.

Dumas, B. (1994): "Partial equilibrium versus general equilibrium models of the international capital market", in The Handbook of International Economics, edited by F. van der Ploeg, chap. 10, Oxford: Blackwell. 
Enders, W. K. and C. W. J. Granger (1998): "Unit root tests and asymmetric adjustment with an example using the term structure of interest rates", Journal of Business and Economics Statistics, vol. 16, pp. 304-311.

Frenkel, J. A. (1978): "Purchasing power parity: doctrinal perspective and evidence from de 1920s", Journal of International Economics, vol. 8, pp. 169-191.

Giannellis, N. and A. Papadopoulos (2006): "Purchasing power parity among developing countries and their trade-partners. Evidence from selected CEECs ans implications for their membership of EU", Working Paper, University of Crete.

Hegwood, N. D. and D. Papell (1998): "Quasi purchasing power parity", International Journal of Finance and Economics, vol. 3, pp. 279-289.

Kapetanios, G., Y. Shin and A. Snell (2003): "Testing for a unit root in the nonlinear STAR framework", Journal of Econometrics, vol. 112, pp. 359379 .

Kilian, L. and M. P. Taylor (2003): "Why is it so difficult to beat the random walk forecast of exchange rates?", Journal of International Economics, vol. 60 , pp. 85-107.

Krugman, P. R. (1978): "Purchasing power parity and exchange rates: Another look at the evidence", Journal of International Economics, vol. 8, pp. 397-407.

Larsson, R., J. Lyhagen and M. Lothgren (2001): "Likelihood-based cointegration tests in heterogeneous panels", Econometrics Journal, vol. 4, pp. 109-142.

Masters, N. (2006): "Purchasing power parity in the long run: An analysis of exchange rate and price behaviour for Central and Eastern European countries", Unpublished Manuscript.

Michael, P., A. Nobay and D. Peel (1997): "Transaction costs and nonlinear adjustment in real exchange rates: An empirical investigation", Journal of Political Economy, vol. 105, pp. 862-879.

Ng, S. and P. Perron (2001): "Lag selection and the construction of unit root tests with good size and power", Econometrica, vol. 69, pp. 1519-1554. 
Obstfeld, M. and M. P. Taylor (1997): "Nonlinear aspects of goods-market arbitrage and adjustment: Hekscher's commodity point revisted", Journal of the Japanese and International Economics, vol. 11, pp. 441-479.

Ouliaris, S., J. Y. Park and P. C. B. Phillips (1989): "Testing for a unit root in the presence of a maintained trend", in Advances in Econometrics and Modelling, edited by B. Raj, Kluwer, pp. 6-28.

Perron, P. and P. C. B. Phillips (1987): "Does GNP have a unit root? A reevaluation", Economics Letters, vol. 23, pp. 139-145.

Sarno, L. (2000): "Real exchange rate behaviour in the Middle East: A re-examination", Economics Letters, vol. 66, pp. 127-136.

Sideris, D. (2006): "Purchasing power parity in economies in transition: Evidence from Central and East European countries", Applied Financial Economics, vol. 16, pp. 135-143.

Taylor, M. P. (2004): "Is official exchange rate intervention effective?", Economica, vol. 71, pp. 1-12.

Taylor, M. P. and D. A. Peel (2000): "Nonlinear adjustment, long-run equilibrium and exchange rate fundamentals", Journal of International Money and Finance, vol. 19, pp. 33-53.

Taylor, M. P., D. A. Peel and L. Sarno (2001): "Nonlinear mean-reversion in real eschange rates: Towards a solution to the purchasing power parity puzzles", International Economic Review, vol. 42, pp. 1015-1042.

Thacker, N. (1995): "Does PPP hold in the transition economies? The case of Poland and Hungary", Applied Economics, vol. 27, pp. 477-481.

Wei, S.-J. and D. C. Parsley (1995): "Purchasing power disparity during the float rate period: Exchange rate volatility, trade barriers and other culprits", Working Paper 5032, NBER.

West, K. D. (1988): "Asymptotic normality when regressors have a unit root", Econometrica, vol. 56, pp. 1397-1418. 